\title{
ANALSISIS DISPARITAS PENDAPATAN ANTAR WILAYAH DI DAERAH PENYANGGA SURABAYA
}

\author{
Dwi Reza Khusnul Khuluk \\ Email: Dwirezakhusnul21@gmail.com \\ Program Studi Ekonomi Pembangunan Universitas Pembangunan Nasional Veteran” Jawa \\ Timur \\ Jl. Rungkut Madya No.1, Gn. Anyar, Kec. Gn. Anyar, Kota SBY, Jawa Timur 60294 \\ Sri Muljaningsih \\ Email: muljaningsihsri@gmail.com \\ Program Studi Ekonomi Pembangunan Universitas Pembangunan Nasional Veteran” Jawa \\ Timur \\ Jl. Rungkut Madya No.1, Gn. Anyar, Kec. Gn. Anyar, Kota SBY, Jawa Timur 60294
}

\author{
Kiki Asmara \\ Email: kikyasmara25@gmail.com \\ Program Studi Ekonomi Pembangunan Universitas Pembangunan Nasional Veteran” Jawa \\ Timur \\ Jl. Rungkut Madya No.1, Gn. Anyar, Kec. Gn. Anyar, Kota SBY, Jawa Timur 60294
}

\begin{abstract}
ABSTRAK
Penelitian ini bertujuan untuk mengetahui dan menganalisis besarnya disparitas antar Daerah, serta mengetahui sektor-sektor yang mnejadi basis dari daerah-daerah tersebut yang nantinya dapat dikembangan oleh Pemerintah Daerah yang bersangkutan, dan juuga mengklasifikasikan daerah Kabupaten/Kota yang berdasarkan pertumbuhan ekonomi dan juga pendapatan perkapita masinhmasing daerah. meenggunakan metode analisis Location Quontient (LQ), Shift-Share (SS), Tipologi Klassen, Indeks Williamson, dan juga pembuktian hipotesis Kuznets "U" Terbalik. daiantara 6 Kabupaten/Kota yang ada di daerah penyangga Surabaya terdapat 1 wilayah yang termasuk kedalam daerah tertinggal, tingkat disparitas di daerah penyangga Surabaya sesuai Indeks Williamson sebesar 0,90. Hipotesis Kuznets tentanng teori "U" terbalik tidak berlaku di wilayah ini, hal ini berarti seiting bertambahnya pembangunan tidak mengurangi tingkat ketimpangan di daerah penyangga Surabaya yang memiliki tingkat disparitas yang tinggi
\end{abstract}

Kata Kunci: Ketimpangan Pendapatan antar daerah; Indeks Williamson; Tipologi Klassen; Hipotesis Kuznet

\section{ABSTRACT}

This research aims to find out and analyze the magnitude of disparity between regions, knowing the sectors that are the basis of these areas that can later be developed by the local government concerned, and also to classify districts / cities based on economic growth and income per capita of each region. using Location Quontient (LQ), Shift-Share (SS), Klassen Typology, Williamson Index, and also proof of The Reverse Kuznets "U" hypothesis. Among of 6 districts / cities in the buffer zone of Surabaya there is 1 area that belongs to the lagging area, the level of disparity in the buffer area of Surabaya according to the Williamson Index of 0.90 . Kuznets hypothesis tentanng the theory of " $U$ " upside down does not apply in this region, this means that the increase in development does not reduce the level of inequality in the buffer area of Surabaya which has a high level of disparity.

Key Words: Income inquality, Indeks Williamson, Tipologi Klassen, Hipotesis Kuznet 


\section{PENDAHULUAN}

Daerah Penyangga Surabaya sendiri yang terletak di Satuan Wilayah Pengembangan Gerbangkertasusila yang dibuat untuk mendorong pembnagunan dan pertumbuhan ekonomi si wilayah-willayah tersebut dengan Kota Surabaya sebagai Growth Pole namun pada realisasinya masih adanya daerah yang pertumbuhan ekonominya belum baik dan lebih kecil dibanding daerah lainnya. Sesuai dengan gambar 1 dapat diketahui bahwa Pertumbuhan ekonomi di Daerah Penyangga Kota Surabaya sesuai dengan yang dikeluarkan Badan Pusat Statistik Provinsi Jawa Timur terlihat bahwa terdapat bahwa pertumbuhnya memiliki perbedaan yang besar diantara beberapa wilayahnya. Selama tahun 2014 sampai dengan 2019 terlihat bahwa Kabupaten Sidoarjo dan Kabupaten Mojokerto memiliki pertumbuhan yang cukup stabil, Kabupaten Gresik, Kabupaten Lamongan, Kota Mojokerto dan Kabupaten Bangkalan memiliki pertumbuhan yang fluktuatif. Namun Kabupaten Bangkalan memiliki pertumbuhan yang cenderung menurun dimana pada tahun 2014 memiliki pertumbuhan sebesar 7\% namun dan menjadi pertumbuhan ekonomi yang paling tinggi namun pada tahun 2015 pertumbuhan ekonomi Kabupaten Bangkalan memiliki nilai sebesar -2\%.

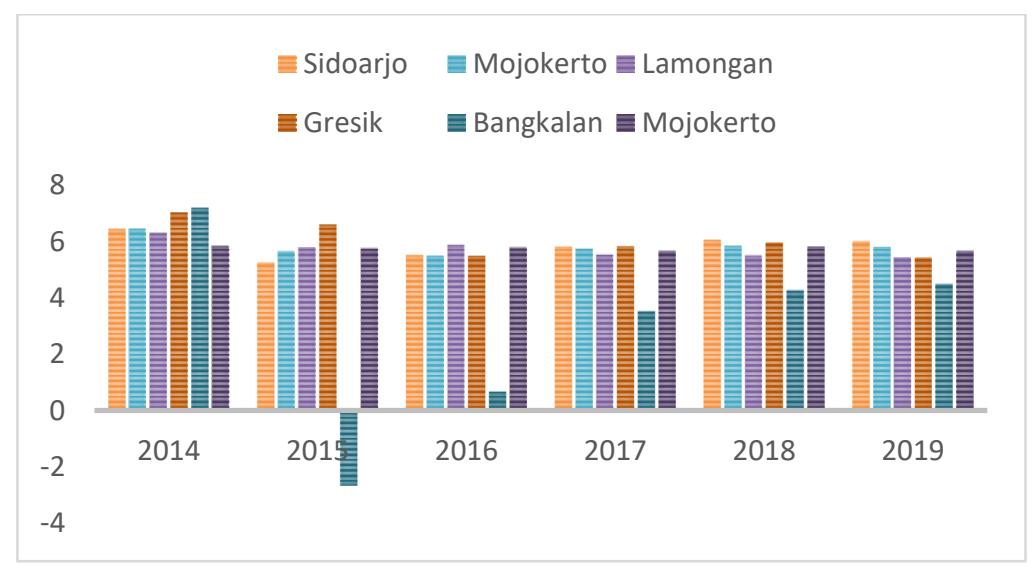

Gambar.1Pertumbuhan Ekonomi Daerah Penyangga Surabaya 2014-2019

Sumber: BPS Jawa Timur, 2020 (data diolah)

Disparitas Pendapatan di wilayah ini sesuai dengan data yang terbitkan oleh Badan Pusat Statistik (BPS) Jawa Timur menunjukkan bahwa tingkat Gini rasio pada tahun yang ada di Daerah penyangga Surabaya tertinggi terjadi pada tahun 2017 yakni Kota Mojokerto dengan nilai 0,39. Namun secara keseluruhan Daerah Penyangga Surabaya memiliki tingkat ketimpangan yang rendah jika dihitung dengan indeks gini,

Tabel 1

Indeks Gini Daerah Penyangga Surabaya

\begin{tabular}{|l|c|c|c|c|c|}
\hline Indeks Gini & $\mathbf{2 0 1 5}$ & $\mathbf{2 0 1 6}$ & $\mathbf{2 0 1 7}$ & $\mathbf{2 0 1 8}$ & $\mathbf{2 0 1 9}$ \\
\hline Kabupaten Sidoarjo & & & & & \\
& 0.35 & 0.37 & 0.34 & 0.35 & 0.31 \\
\hline
\end{tabular}




\begin{tabular}{|l|r|r|r|r|l|} 
Kabupaten Mojokerto & 0.31 & 0.3 & 0.32 & 0.31 & 0.27 \\
\hline Kabupaten Lamongan & 0.3 & 0.3 & 0.32 & 0.31 & 0.32 \\
\hline Kabupaten Gresik & 0.31 & 0.33 & 0.29 & 0.27 & 0.28 \\
\hline Kabupaten Bangkalan & 0.32 & 0.31 & 0.3 & 0.29 & 0.31 \\
\hline Kota Mojokerto & 0.36 & 0.37 & 0.39 & 0.34 & 0.31 \\
\hline Jawa Timur & $\mathbf{0 . 4 2}$ & $\mathbf{0 . 4}$ & $\mathbf{0 . 4}$ & $\mathbf{0 . 3 8}$ & $\mathbf{0 . 3 7}$ \\
\hline
\end{tabular}

Sumber: BPS Jawa Timur (2020)

Pendapatan perkapita dari daerah Penyangga Surabaya yang terbesar dimiliki Kabupaten Gresik dalam kurun waktu tahun 2015 sampai dengan 2016. Sedangkan untuk yang terkecil dimiliki Kabupaten Bangkalan.

Tabel 2

Pendapatan Perkapita Daerah Penyangga Surabaya

\begin{tabular}{|r|r|r|r|r|r|}
\hline kabupaten/ kota & $\mathbf{2 0 1 5}$ & $\mathbf{2 0 1 6}$ & $\mathbf{2 0 1 7}$ & $\mathbf{2 0 1 8}$ & $\mathbf{2 0 1 9}$ \\
\hline Kab. Bangkalan & $17,716.50$ & $17,676.20$ & $22,304,00$ & $24,362.00$ & $25,009.00$ \\
\hline Kab. Lamongan & $18,788.40$ & $19,882.00$ & $28,836.00$ & $31,312.00$ & $33,415.00$ \\
\hline Kota Mojokerto & $31,753.20$ & $33,398.30$ & $45,791.00$ & $49,375.00$ & $52,780.00$ \\
\hline Kab. Mojokerto & $43,310.20$ & $45,245.30$ & $64,359.00$ & $69,164.00$ & $73,716.00$ \\
\hline Kab. Sidoarjo & $52,903.60$ & $54,954.30$ & $79,764.00$ & $85,300.00$ & $90,697.00$ \\
\hline Kab. Gresik & $64,762.00$ & $67,549.50$ & $92,232.00$ & $100,39.00$ & $105,907.00$ \\
\hline
\end{tabular}

Sumber: BPS Jawa Timur,2020

Perbedaan pertumbuhan ekonomi, pendapatan perkapita tiap daerah yang terjadi menunjukkan bahwa adanya ketimpangan pendapatan antara Kabupaten/Kota yang ada di Daerah Penyangga Surabaya, wilayah yang ada di Daerah Penyangga Surabaya ini memiliki kecenderungan geografi yang serupa dan sama-sama memiliki kedekatan dengan Kota Surabaya yang merupakan Growth Pole yang diharapkan dapat memudahkan mobilisasi dan pembangunan ekonomi di setiap daerah. Penelitian yang dilakukan oleh Denny Iswanto menunjukkan bahwa dua dari 6 wilayah yang ada di daerah penyangga Surabaya tergolong kedalam daerah tertinggal yakni Kabupaten Bangkalan dan Kab Mojokerto. Kabupaten Sidoarjo dan Kota Mojokerto masuk kedalam daerah berkembang. Kabupaten Lamongan masuk kedalam daerah maju tapi tertekan dan yang terakhir Kabupaten Gresik masuk kedalan daerah yang maju dan bertumbuh cepat (Denny Iswanto,2012)

Oleh karena itu penelitian ini ditujukan untuk mengetahui seberapa besar ketimpangan pendapatan yang ada di daerah Penyangga Surabaya, yang kemudian menentukan sektor-sektor unggulan yang ada di kawasan tersebut agar nantinya pertumbuhan ekonomi akan tercapai secara optimal sehingga nantinnya ketimpangan pendapatan penduduk 
antara daerah-daerah tersebut. sehingga nantinya ketimpangan menjadi lebih rendah, menurunkan kesenjangan sosial, serta dapat meningkatkan kesejahteraan penduduk yang berada di daerah-daerah tersebut.

Mankiw (2006) menafsirkan sebenarnya teori pertumbuhan baru akan memberikan kerangka teoritis yang nantinya digunakan untuk menganalisis pertumbuhan. Kemajuan teknologi bersifat endogen. Pertumbuhan adalah bagian dari keputusan peserta ekonomi untuk berinvestasi dalam pengetahuan. Ketika modal yang berkembang tidak hanya modal fisik tetapi juga modal manusia, maka peran modal bukan hanya sebagai bagian dari pendapatan. Kemajuan teknologi bersifat endogen; pertumbuhan merupakan bagian dari keputusan pelaku ekonomi untuk berinvestasi dalam pengetahuan. Pertumbuhan ekonomi dilihat dari bagaimana pertumbuhan Pendapatan Domestik Regional Bruto (PDRB) yang di dapatkan oleh masing masing daerah, semakin besarnya PDRB daerah maka dapat dinilai bahwa pertumbuhan ekonomi yang dimiliki daerah tersebut semakin besar.

Menurut KBBI disparitas adalah perbedaan, biasanya disparitas di sebut juga ketimpangan yang berarti hal yang tidak sebagaimana mestinya. Smith dan Todaro (2006) ketimpangan pendapatan merupakan disparitas pendapatan yang didapatkan masyarakat sehingga menimbulkan tidak meratanya distribsusi pendapatan dalam suatu wilayah di tengah masyarakat. Sukirno (2006) menjelaskan bahwa ketimpangan dsitribusi pendapatan dapat dibedakan menjadi dua yakni ketimpangan absolut, dimana ketimpangan ini menggunakan parameter nilai mutlak, dan yang kedua adalah ketimpangan realtif ketimpangan yang dinilai dari membandingkan besar kecilnya pendapatan yang diterima seseorang atau sekelompok anggota masyarkat dengan total pendapatan yang diterima oleh masyarakat yang ada di wilayah tertentu secara keseluruhan. Sehingga dapat disimpulkan bahwa ketimpanngan pendapatan adalah adanya perbedaan atau ketidakmerataan pendapatan antar daerah yang disebabkan karena adanya perbedaan jenis faktor ekonomi dan sumberdaya yang dimiliki oleh daerah tertentu.

\section{METODE PENELITIAN}

Penelitian yang dilakukan merupakan penilitian Kuantitatif yang dalam pengerjaan dan analisisnya di fokuskan pada data-data numerical (angka) yang nantinya diolah penulis, alat analisi yang dugunakan penulis adalah sebagai berikut: 


\section{A. Analisis Location Quotient (LQ)}

Sebuah alat hitung digunakan untuk mengevaluasi kinerja sektoral PDRB, melihat sektor yang menjadi basis dan bukan basis di suatu daerah. Teknik analisis LQ dihitung menggunakan rumus:

$$
L Q J i=\frac{V A J i /{ }_{V A I i}}{P D R B J / P D R B I}
$$

Keterangan:

LQJi= Location Quatient

VAJi= Nilai sektor i di daerah Kota/Kabupaten

VAIi $=$ Nilai sektor i di tingkat Provinsi

PDRBJ=PDRB Kota/Kabupaten

PDRBI = PDRB Provinsi (Morrissey, 2014)

Nantinya hasil yang diperoleh, dapat diartikan ke dalam dua kategori sektor yaitu:

1. Basis: apabila nilai $L Q>1$.

2. Non Basis : apabila nilai LQ $</=1$.

\section{B. Analisis Shift Share}

Sebuah alat analisis yang digunakan untuk menetapkan bagaimana produktivitas kerja dari perekonomian daerah dengan cara membandingkan daerah yang kecil dengan daerah yang lebih besar. Metode ini dapat digunakan untuk memprediksi pertumbuhan ekonomi pada suatu wilayah, dan sebagai alat analisis untuk mempelajari pembangunan desa (Khusaini,2015). Analisis ini memiliki tiga informasi dasar yang saling berhubungan, yaitu:

1. Pertumbuhan ekonomi nasional (National Share)

Melihat bagaimana Pengaruh pertumbuhan ekonomi nasional atas perekonomian daerah, nilai dari uji bernilai positif apabila pertumbuhan ekonomi daerah lebih cepat ketimbang pertumbuhan ekonomi dari daerah yang lebih besar.

2. Pergeseran Proporsional (Proposional Shift)

Melihat bagaimana kondisi ekonomi di suatu wilayah apakah wilayah tersebut lebih memfokuskan pada industri yang memiliki pertumbuhan lebih cepat dibandingkan perekonomian di wilayah yang menjadi acuan wilayah teresbut.

3. Pergeseran Differensial (Differensial Shift)

DS Bertujuan untuk menghitung seberapa besar Shift regional netto yang dikarenakan sektor-sektor industri tertentu yang tumbuh lebih cepat atau lebih lambat dari faktor 
lokasional internal. Untuk pengukuran Shift Share dapat di hitung dengan persamaan dibawah ini:

$$
\begin{gathered}
P R_{i j}=Q_{i j}^{0}\left\{\frac{Y_{t}}{Y_{0}}-1\right\} \ldots \ldots(1) \\
P S_{i j}=Q_{i j}^{0}\left\{\frac{Q_{i}^{t}}{Q_{i}^{0}}-\frac{Y_{t}}{Y_{0}}\right\} \ldots \ldots \\
D S_{i j}=Q_{i j}^{0}\left\{\frac{Q_{i j}^{t}}{Q_{i j}^{0}}-\frac{Q_{i}^{t}}{Q_{i}^{0}}\right\} \ldots \ldots
\end{gathered}
$$

Dimana:

$\mathrm{Yt} \quad=$ PDRB Provinsi periode tahun $\mathrm{n}$

Y0 = PDRB Provinsi pada periode tahun dasar

Qit $\quad=$ PDRB Provinsi sektor i pada tahun $\mathrm{n}$

Qi0 = PDRB Provinsi sektor i pada tahun dasar

Qijt $\quad=$ PDRB Kabupaten/Kota pada tahun $n$

Qijt = PDRB Kabupaten/Kota pada tahun dasar (Khusaini, 2015)

\section{Tipologi Klaseen}

Tipologi klassen sebuah alat yang berfungsi untuk mengklasifikasikan daerah. Tipologi klassen menggunakan dua indikator paling utama yakni pertumbuhan ekonomi serta pendapatan perkapita daerah, dengan menggunakan dua variabel akan diklasifikasikan menjadi empat model, yakni

Tabel 3. Klasifikasi tipologi klassen

\begin{tabular}{|c|c|c|}
\hline $\mathrm{r}$ & yi $<\mathrm{y}$ & yi $>\mathrm{y}$ \\
\hline $\mathrm{ri}>\mathrm{r}$ & $\begin{array}{c}\text { Daerah } \\
\text { Berkembang } \\
\text { Cepat (III) }\end{array}$ & $\begin{array}{c}\text { Daerah } \\
\text { Maju Cepat } \\
\text { dan Cepat } \\
\text { Tumbuh (I) }\end{array}$ \\
\hline & Daerah & Daerah \\
ri $<\mathrm{r}$ & Relatif \\
& $\begin{array}{c}\text { Tertinggal } \\
\text { (IV) }\end{array}$ & $\begin{array}{c}\text { Tertekan } \\
\text { (II) }\end{array}$ \\
\hline
\end{tabular}

Sumber: Emilia Imelia, 2006

Keterangan:

Ri: Tingkat Pertumbuhan ekonomi Kabupaten/Kota

r : Tingkat Pertumbuhan ekonomi Provinsi 
yi: PDRB per kapita Kabupaten/Kota

y : PDRB per kapita Provinsi

\section{Indeks Williamson}

Menganalisis bagaimana kesenjangan antar wilayah/daerah melalui perhitungan Indeks Williamson, menggunakan perhitungan PDRB per kapita dengan jumlah penduduk di daerah tertentu. Untuk menghitung ketimpangan pendapatan antar daerah menggunakan Indeks Williamson menggunakan rumus:

$$
C V_{w}=\sqrt{\frac{\sum(Y i-Y x)^{2} f i / n}{Y x}}
$$

Keterangan:

$\mathrm{CVw}=$ Indeks Williamson

$\mathrm{Fi} \quad=\sum$ penduduk provinsi ke-i (jiwa)

$\mathrm{N}=\sum$ penduduk indonesia (jiwa)

$\mathrm{Yi} \quad=\mathrm{PDRB}$ per kapita provinsi ke-i

Yx = PDRB per kapita rata-rata indonesia

Hasil yang didapatkan dari hasil perhitungan Indeks Williamson nantinya akan disimpulkan kedalam kriteria sebagai berikut:

Nilai 0,0 s/d 0,2 menandakan ketimpangan distribusi pendapatan yang rendah.

Nilai 0,21 s/d 0,35 menandakan tingkat ketimpangan dstribusi pendapatan sedang.

Nilai > 0,35 menandakan ketimpangan distribusi pendapatan yang tinggi (Saputra,2016)

\section{E. Pembuktian Teori Kuznets}

Kuznets dalam (Kuncoro,2006) Kuzents menyatakan bahwa tahap awal saat dilakukannya pembangunan ekonomi akan mengakibatkan penurunan dari distrobusi pendapatan dan ketika sudah berada ditahap yang lebih tinggi maka dsitribusi pendaoatnnnya akan meningkat, namun nantinya akan menurun kembali. Hak ini digambarkan di dalam kurva 3.1, yang memperlihatkan bahwa dalam jangka pendek terdapat hubungna yang positif antara pertunbuhan pendapatan perkapita dengan distribusi pendapatan. Tetapi jika di bandingkan dengan jangka panjang maka keduanya akan memberikan korelasi yang negatif 


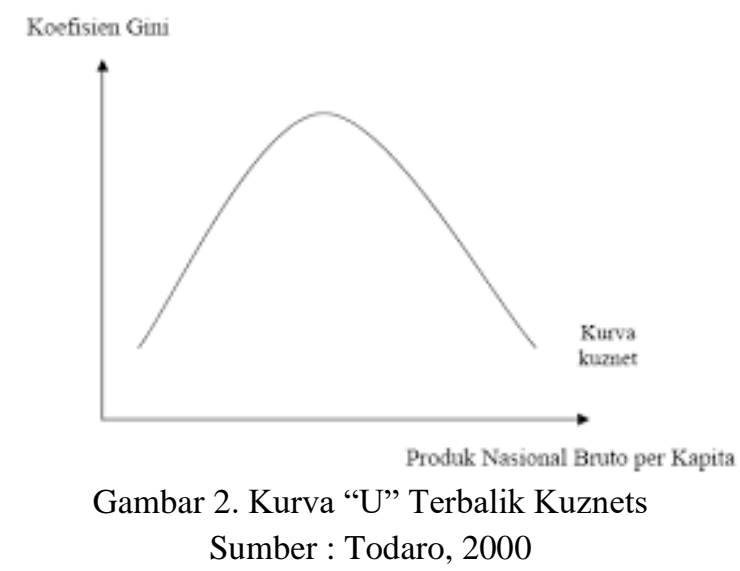

\section{HASIL DAN PEMBAHASAN}

\section{A. ANALISIS LQ}

Hasil perhitungan LQ diatas terlihat bahwa Kabupaten/Kota yang ada di Daerah Penyangga Surabaya memiliki sektor basis dan non basis yang berbeda. Sektor basis dari masing-masing wilayah adalah sebagai berikut:

Tabel 4. Locatipn Quotient

Daerah Penyangga Surabaya Tahun 2015-2019

\begin{tabular}{|c|c|c|c|c|c|c|}
\hline SEKTOR & Bangkalan & Gresik & Lamongan & Sidoarjo & Mojokerto & Kota Mojokerto \\
\hline Pertanian, Kehutanan dan Perikanan & 1.87 & 0.58 & 3.08 & 0.19 & 0.66 & 0.05 \\
\hline Pertambangan dan Penggalian & 6.04 & 2 & 0.24 & 0.02 & 0.17 & 0 \\
\hline Industri Pengolahan & 0.08 & 1.6 & 0.3 & 1.68 & 1.83 & 0.36 \\
\hline Pengadaan Listrik dan Gas & 0.14 & 1.76 & 0.25 & 2.91 & 0.23 & 0.3 \\
\hline Pengadaan Air, Pengelolaan Sampah, Limbah dan Daur Ulang & 0.75 & 0.62 & 1.13 & 0.79 & 0.7 & 1.34 \\
\hline Konstruksi & 1.22 & 0.99 & 1.17 & 1 & 0.98 & 1.18 \\
\hline Perdagangan Besar dan Eceran & 0.78 & 0.66 & 1.09 & 0.88 & 0.58 & 1.62 \\
\hline Transportasi dan Pergudangan & 0.45 & 0.73 & 0.28 & 2.71 & 0.4 & 0.88 \\
\hline Penyediaan akomodasi dan makanan & 0.2 & 0.22 & 0.29 & 0.65 & 0.37 & 1.19 \\
\hline Informasi dan Komunikasi & 0.91 & 0.76 & 1.42 & 0.76 & 1.16 & 2.53 \\
\hline Jasa Keuangan dan Asuransi & 0.63 & 0.41 & 0.79 & 0.46 & 0.57 & 2.84 \\
\hline Real Estate & 0.63 & 0.74 & 1.28 & 0.56 & 0.91 & 1.61 \\
\hline Jasa Perusahaan & 0.28 & 0.34 & 0.36 & 0.2 & 0.2 & 0.95 \\
\hline Administrasi Pemerintahan, Pertanahan dan Jaminan Sosial & 2.17 & 0.52 & 1.82 & 0.77 & 1.04 & 2.04 \\
\hline Jasa Pendidikan & 1.33 & 0.32 & 1.04 & 0.44 & 0.5 & 1.64 \\
\hline Jasa Kesehatan dan Kegiatan Sosial & 0.55 & 0.57 & 1.37 & 0.49 & 0.59 & 1.78 \\
\hline Jasa Lainnya & 0.49 & 0.19 & 1.36 & 0.27 & 0.65 & 2.62 \\
\hline
\end{tabular}

Sumber: BPS, Data diolah (2020)

Berdasarkan hasil perhitungan LQ Pertanian, Kehutanan, Perikanan Menjadi sektor basis di beberapa daerah yakni, Kabupaten Bangkalan dan Kabupaten Lamongan. Pertambangan \& Penggalian Sektor ini menjadi basis di dua wilayah Kabupaten Bangakalan dan Kabupaten Gresik. Industri Pengolahan adalah Sektor basis di daerah Kabupaten Gresik, Kabupaten Sidoarjo, Kabupaten Mojokerto. Pengadaan listrik \& gas Sektor ini menjadi sektor basis di dua daerah yakni Kabupaten Gresik dan Kabupaten Sidoarjo. Pengadaan air, pengelolaan, sampah, limbah dan daur ulang menjadi sektor basis di Kabupaten Lamongan 
dan Kota Mojokerto. Sektor Konstruksi menjadi sektor basis Kabupaten Bangkalan, Kabupaten Lamongan, Kota Mojokerto. Pengadaan besar dan eceran menjadi sektor basis di Kabupaten Lamongan dan Kota Mojokerto. Transportasi dan Pergudangan sektor basis ini hanya dimiliki Kabupaten Sidoarjo. Informasi dan Komunikasi menjadi sektor basis di wilayah Kabupaten Lamongan, Kab. Mojokerto, Kota Mojokerto. Jasa keuangan dan asuransi menjadi sektor basis di Kota Mojokerto. Real estate Sektor ini menjadi sektor basis di Kota Mojokerto. Administrasi pemerintahan, pertanahan, dan jaminan sosial Sektor ini menjadi basis di Kabupaten Bangkalan, Kabupaten Lamongan, Kabupaten Mjojokerto. Jasa Pendidikan Menjadi sektor basis di Kabupaten bangkalan, Kabupaten Lamongan, Kota Mojokerto. Jasa Kesehatan dan kegiatan sosial merupakan sektor basis di Kabupaten Lamongan, Kota Mojokerto. Jasa lainnya Sektor basis ini dimiliki Kabupaten Lamongan dan Kota Mojokerto. Sedangkan untuk sektor jasa perusahaan dan penyedaian akomodasi makan dan minum tidak menjadi sketir basis di antara seluruh daerah penyangga Surabaya.

\section{B. ANALISIS SHIFT SHARE}

\section{- PS}

Tabel 5. Analisis PS

Daerah Penyangga Surabaya Tahun 2015-2019

\begin{tabular}{|l|r|r|r|r|r|r|}
\hline SEKTOR & Kab. Bangkala Kab. Gresik & Kab. Lamongan & Kab. Sidoarjo & Kab. Mojokert Kota Mojokert \\
\hline Pertanian, Kehutanan dan Perikanan & -154640.56 & -250835.37 & -359933.46 & -109322.87 & -162134.27 & -1062.17 \\
\hline Pertambangan dan Penggalian & 78720.61 & 95860.43 & 2667.95 & 1563.75 & 4691.54 & 0.00 \\
\hline Industri Pengolahan & 2248.82 & 243488.04 & 12943.18 & 348904.21 & 160383.51 & 2709.06 \\
\hline Pengadaan Listrik dan Gas & -394.67 & -25597.16 & -947.31 & -61862.17 & -1902.87 & -208.75 \\
\hline Pengadaan Air, Pengelolaan Sampah, Limbah dan Daur Ular & -41.57 & -180.73 & -90.07 & -314.84 & -116.55 & -18.97 \\
\hline Konstruksi & 5098.40 & 23237.07 & 6533.15 & 28690.34 & 11271.18 & 1176.58 \\
\hline Perdagangan Besar dan Eceran & 11999.92 & 52870.50 & 23674.68 & 95589.50 & 26314.05 & 6275.58 \\
\hline Transportasi dan Pergudangan & 666.49 & 5465.27 & 526.75 & 30713.17 & 1928.85 & 331.58 \\
\hline Penyediaan akomodasi dan makanan & 4088.81 & 23481.71 & 8231.31 & 94530.73 & 22332.23 & 6204.85 \\
\hline Informasi dan Komunikasi & 13076.67 & 666397179.53 & 343326946.84 & 9444427331.64 & 604046152.68 & 111458967.27 \\
\hline Jasa Keuangan dan Asuransi & -1506.92 & -5304.98 & -2720.77 & -7985.67 & -4105.68 & -1717.94 \\
\hline Real Estate & -341.39 & -1987.31 & -910.57 & -2212.83 & -1544.70 & -236.43 \\
\hline Jasa Perusahaan & 200.15 & 1284.34 & 360.21 & 1020.15 & 414.17 & 169.18 \\
\hline Administrasi Pemerintahan, Pertanahan dan Jaminan Sosial & -12162.46 & -15044.91 & -14410.54 & -30930.66 & -17276.65 & -2891.60 \\
\hline Jasa Pendidikan & 2043.74 & 2497.92 & 2230.61 & 4656.04 & 2227.80 & 617.32 \\
\hline Jasa Kesehatan dan Kegiatan Sosial & 665.10 & 3627.41 & 2364.12 & 4264.47 & 2146.17 & 552.15 \\
\hline Jasa Lainnya & -478.23 & -947.29 & -1862.70 & -1850.99 & -1882.11 & -650.87 \\
\hline PDRB & & & & & &
\end{tabular}

Sumber; BPS , data diolah (2020)

Melalui tabel di atas diketahui bahwa keseluruhan dari kab/kota yang ada di Daerah penyangga Surabaya memiliki sepuluh sektor ekonomi yang mendapatkan nilai nilai PS >0, yang memiliki arti pertmbuhan ekonomi yang ada di daerah lebih cepat dibandingkan dengan pertumbuhan ekonomi Provinsi Jawa Timur. Sepuluh sektor tersebut adalah Pertambangan dan Penggalian, industri pengolahan, konstruksi, perdagangan besar dan eceran, transportasi 
dan pergudangan, penyediaan akomodasi dan makanan, informasi dan komunikasi, jasa perusahaan, jasa pendidikan, dan jasa kesehtan dan kegiatan sosial.

\section{- $\mathbf{P R}$}

Jika score yang diapatkan 1 maka sektor tersebut adalah sektor pendorong ekonomi di wilayah tersebut. dimana nilai PR $>\Delta$ Qij

Tabel 6

Hasil hitung PR Daerah Penyangga Surabaya

2015-2019

\begin{tabular}{|c|c|c|c|c|c|c|c|c|c|c|c|c|}
\hline PR & Bangh & & Gresi & & Lamon & & Sidider & & Kota Moj & jokerto & Kab. Moj & jokerto \\
\hline SEKTOR & RATA-RATA & Rata-Rata $\triangle Q i j$ & RATA-RATA $\mathrm{R}$ & Rata-Rata $\Delta Q \mathrm{Qij}$ & RATA-RATA & Rata-Rata $\triangle Q i j$ & RATA-RATA & Rata-Rata $\Delta Q$ iij & RATA-RATA & Rata-Rata $\triangle$ Qii] & RATA-RATA & Rata-Rata $\triangle Q \mathrm{Qij}$ \\
\hline Pertanian, Kehutanan dan Perikanan & 19832430 & 58428.20 & 318,052424 & $161,824.65$ & $227,866.29$ & $128,862.86$ & $26,166.71$ & $22,490.14$ & $1,3646.63$ & 280.31 & 208,51237 & 39,720203 \\
\hline Pertambangan dan Penggalian & 323119.84 & -334781.60 & $509,284.12$ & $262,607.48$ & $68,471.20$ & $9,678.20$ & $115,418.69$ & 7,30254 & 0.000 & 0.00 & $25,147,55$ & 12,81259 \\
\hline Industri Pengolahan & 2048.02 & 18848.40 & $2,274,742,91$ & $2,240,647.36$ & 42,262.01 & 112,1999.44 & $580,519,83$ & $6013,344.12$ & 24998.33 & $24,653.61 \mid$ & $1,466,299.31$ & $1,330,264.22$ \\
\hline Pengadaan Listrik dan Gas & 403.64 & 321.60 & $26,090.25$ & $19,202.19$ & 400.66 & 688.38 & $2,676,539.48$ & $3,209,387.82$ & 213.03 & 163.99 & $1,943.50$ & $1,616.05$ \\
\hline Pengadaan Air, Pengelolaan Sampah, Limbah dan Daur Ulang & 684.86 & 508.20 & $2,879.71$ & $2,956.63$ & 697.11 & $1,053.88$ & $50,429,60$ & $-15,078.62$ & 308.47 & 23275 & $1,871.10$ & $1,530.26$ \\
\hline Konstruksi & 101792.47 & 132997.20 & $421,087.85$ & $715,488.07$ & $76,488.68$ & $115,251.60$ & $110,617.83$ & $75,245.58$ & $25,366,74$ & $24,286.63$ & $246,424.86$ & $222,096.76$ \\
\hline Perdagangan Besar dan Eceran & 132101.96 & |55140.20| & $577,36,45$ & $775,752.10$ & 128,922,87 & $188,498.36$ & $679,299.96$ & $722,861.92$ & $69,235.57$ & $74,641.75$ & $290,372.93$ & $305,553.99$ \\
\hline Transportasi dan Pergudangan & 12067.73 & 131892.20 & $101,083.67$ & 143,658.73 & $6,570.86$ & $9,054.54$ & $962,261.59$ & $1,44,316,98$ & $5,981.03$ & 6967.99 & 31,90241 & $42,599.12$ \\
\hline Penyediaan akomodasi dan makanan & 9584.23 & 1459220 & $55,070.14$ & $89,30.17$ & $9,162,42$ & $23,873.34$ & $480,770.04$ & $169,511.04$ & $14,525,45$ & $19,45.72$ & $52,281.19$ & $70,755.19$ \\
\hline Informasi dan Komunikasi & 46957.42 & 68633.80 & $202,160.74$ & $318,170.13$ & $49,769.37$ & 89,020208 & $232,520.39$ & $323,400.04$ & $33,26.31$ & 42,28238 & $178,795,91$ & $219,014.61$ \\
\hline Jasa Keuangan dan Asuransi & 15093.04 & 13824.60 & $50,888.78$ & $54,579: 43$ & $13,621.94$ & $14,5458.80$ & $247,375.25$ & $321,90,42$ & $17,177,22$ & $15,018.46$ & 40,198.59 & $37,775.80$ \\
\hline Real Estate & 1003383 & 11178.60 & $60,134.09$ & $82,771.07$ & 13,010.82 & $21,419.10$ & $75,456,11$ & $65,042.28$ & 6.540 .65 & $4,984.83$ & $43,125.62$ & $35,37.50$ \\
\hline Jasa Perushhaan & 2048.70 & 200.80 & $12,770.02$ & $17,229.67$ & $1,860.71$ & $2,000.78$ & $53,705.87$ & $55,352.28$ & $1,729,70$ & $1,667.97$ & $4,236.55$ & 4,32240 \\
\hline Administrassi Pemerintahan, Pertanahan dan Jaminan Sosial & 43364.12 & 3811240 & $54,668.02$ & $50,118.18$ & $30,638.33$ & $19,144,70$ & $29,554.86$ & $17,46.10$ & $10,537.71$ & $8,708.64$ & $63,097.87$ & $42,79.01$ \\
\hline Jasa Pendidikan & 32365.02 & 33498.80 & 39,36433 & $55,001.85$ & $20,678.69$ & $23,716.96$ & $105,695.04$ & $81,021.18$ & $10,116,42$ & $9,6262.20$ & $36,103.15$ & $35,255.42$ \\
\hline Iasa Kesehatan dan Kegiatan Sosial & 3003.71 & 4237.00 & $17,976.87$ & $24,522.86$ & $5,081.86$ & $9,897.10$ & $66,70,0.05$ & $66,155.94$ & $2,766.74$ & $2,630.03$ & $10,747,22$ & $11,513,4$ \\
\hline Jasa Lainnya & 6554.21 & 569900 & $13,267.46$ & $16,011.51$ & $11,463.94$ & 12,124,48 & $22,122.85$ & $21,947.72$ & $8,827.77$ & $7,6157.70$ & $25,786.95$ & $22,31.33$ \\
\hline
\end{tabular}

Sumber: BPS, Data diolah (2020)

Berdasarkan hasil perhitunga yang ditunjukkan oleh tabel di atas, Pertambangan \& Penggalian menjadi sektor yang mendorong pertumbuhan ekonomi di Kabupaten Lamongan. Industri Pengolahan menjadi sektor yang mendorong pertumbuhan ekonomi di Kabupaten Lamongan, Kabupaten Mojokerto, Kabupaten Mojokerto dan Kota Mojokerto. Pengadaan air, pengelolaan, sampah, limbah dan daur ulang menjadi pendorong ekonomi di Kabupaten Gresik, Kabupaten Lamongan, Kota Mojokerto. Konstruksi menjadi sektor yang menjadi pendorong ekonomi di dua daerah yakni Kabupaten Bangkalan dan Kabuapten Gresik. Pengadaan besar dan eceran menjadi sektor pendorong ekonomi adalah Kabupaten Gresik, Kabupaten Lamongan, Kabupaten Kota Mojokerto. Transportasi dan Pergudangan merupakan sektor yang mendorong pertumbuhan ekonomi di Kabupaten Gresik, Kabupaten Lamongan, Kabupaten Mojokerto. Penyediaan akomodasi makan \& minum Menjadi sektor pendorong di beberapa daerah yakni Kabupaten Bangkalan, Kabupaten Gresik, Kabupaten Lamongan, Kabupaten Mojokerto. Informasi dan Komunikasi Menjadi sektor yang mendorong ekonomi di Kabupaten Bangkalan, Kabupaten Gresik, Kabupaten Lamongan, Kabupaten Sidoarjo. Jasa keuangan dan asuransi merupakan sektor pendorong ekonomi di wilayah Kabupaten Gresik, Kabupaten Lamongan, Kabupaten Mojokerto, Kabupaten 
Sidoarjo, Kabupaten Mojokerto dan Kota Mojokerto. Real estate adalah sektor yang menjadi sektor pendorong ekonomi di Kabupaten Lamongan, Kabupaten Gresik, Kabupaten Sidoarjo, Kabupaten Mojokerto. Jasa Perusahaan Menjadi sektor pendorong ekonomi di Kabupaten Gresik, Lamongan, Kota Mojokerto. Administrasi pemerintahan, pertanahan, dan jaminan sosial merpakan Sektor pendorong ekonomi di Kabupaten Lamongan dan Kota Mojokerto. Jasa Pendidikan pendorong ekonomi di Kabupaten Gresik, Kabupaten Lamongan, kabupaten Sidoarjo, Kabupaten Mojokerto dan kota mojokerto. Jasa Kesehatan dan kegiatan sosial Kabupaten Bangkalan, Kabupaten Gresik, Kabupaten Lamongan memiliki pendorong ekonomi sektor ini. Jasa lainnya menjadi sektor pendorong ekonomi di Kabupaten Gresik dan Kabupaten Lamongan. Sedangkan untuk sektor jasa pertannian, kehutanan, perikanan dan sektor pengadaan listrik dan gas tidak menjadi sektor pendorong ekonomi makan dan minum tidak menjadi sketir di antara seluruh daerah penyangga Surabaya

- DS

Tabel 7. Analisis DS

Daerah penyangga Surabaya 2015-2019

\begin{tabular}{|c|c|c|c|c|c|c|}
\hline \multicolumn{7}{|l|}{ DS } \\
\hline SEKTOR & Bangkalan & Gresik & Lamongan & Sidoarjo & \multicolumn{2}{|c|}{ Kab. Mojokerto|Kota Mojokerto } \\
\hline Pertanian, Kehutanan dan Perikanan & RATA-RATA & RATA-RATA & RATA-RATA & RATA-RATA & RATA-RATA & RATA-RATA \\
\hline Pertambangan dan Penggalian & 3665177.19 & $94,564.77$ & $33,353.17$ & $1,772.09$ & $-6,676.07$ & -22.15 \\
\hline Industri Pengolahan & 5543637.33 & $-342,537.07$ & -141.62 & $-8,724.96$ & $-17,026.50$ & 0.00 \\
\hline Pengadaan Listrik dan Gas & 399768.14 & $-277,583.59$ & $147,761.85$ & $230,376.24$ & $104,581.40$ & $-2,993.78$ \\
\hline Pengadaan Air, Pengelolaan Sampah, Limbah dan Daur Ulang & 7660.80 & $18,709.10$ & 983.95 & $-23,996.32$ & $1,575.42$ & 159.71 \\
\hline Konstruksi & 12961.35 & 257.65 & 308.44 & -446.74 & -224.29 & -56.75 \\
\hline Perdagangan Besar dan Eceran & 1983927.54 & $271,163.15$ & $31,353.32$ & $7,366.79$ & $-35,599.27$ & $-2,256.69$ \\
\hline Transportasi dan Pergudangan & 2557321.54 & $145,518.15$ & $35,601.94$ & $-33,972.53$ & $-10,733.00$ & -869.41 \\
\hline Penyediaan akomodasi dan makanan & 232449.34 & $37,109.78$ & $5,224.82$ & $-362,884.89$ & $8,767.87$ & 655.38 \\
\hline Informasi dan Komunikasi & 188858.92 & $10,756.32$ & $8,755.71$ & $2,128.50$ & $-3,858.23$ & $-1,284.58$ \\
\hline Jasa Keuangan dan Asuransi & 922256.97 & $-666,281,170.14$ & $21,712.53$ & $4,998.27$ & $-9,515.30$ & -191.24 \\
\hline Real Estate & 288291.75 & $8,995.63$ & $2,028.16$ & 848.81 & $1,682.88$ & -411.12 \\
\hline Jasa Perusahaan & 193633.95 & $24,624.29$ & $10,436.14$ & $4,635.89$ & $-6,243.42$ & $-1,319.39$ \\
\hline Administrasi Pemerintahan, Pertanahan dan Jaminan Sosial & 39353.54 & $3,238.31$ & 344.91 & -391.59 & -268.72 & -230.91 \\
\hline Jasa Pendidikan & 844853.36 & $10,595.07$ & $2,734.12$ & $-10,944.80$ & $-3,042.22$ & $1,076.53$ \\
\hline Jasa Kesehatan dan Kegiatan Sosial & 622022.94 & $13,139.60$ & $9,072.20$ & -580.25 & $-3,095.52$ & $-1,107.54$ \\
\hline Jasa Lainnya & 64308.53 & $2,918.59$ & $3,650.56$ & $-3,534.15$ & $-1,380.24$ & -688.86 \\
\hline PDRB & 124874.15 & $3,691.34$ & 868.58 & -862.75 & $-1,533.51$ & $33,038.47$ \\
\hline
\end{tabular}

Sumber: BPS, data diolah 2020

Hasil dari perhitungan Differentsial shift diambil kesimpulan bahwa apabila nilai hitung > 0 maka sektor tersebut memiliki keuntungan lokalisional. Dari 17 sektor yang ada terdapat satu sektor yang tidak memiliki keuntungan lokasional yakni sektor Pertambangan, dan penggalian dikeseluruhan daerah. Pertanian, Kehutanan, Perikanan Sektor yang mempunyai keuntungan lokasional ini dimiliki oleh 4 kabupaten/kota yakni Kabupaten Bangkalan, Kabupaten Lamongan, Kabupaten Gresik, Kabupaten Sidoarjo. Industri Pengolahan menjadi sektor yang memiliki keuntungan lokasional di Kabupaten Lamongan 
dan Kabupaten Sidoarjo. Pengadaan listrik \& gas Sektor ini memiliki kentungan lokasional di Kabupaten Bangkalan, Kabupaten Gresik, Kabupaten Mojokerto, dan Kota Mojokerto. Pengadaan air, pengelolaan, sampah, limbah dan daur ulang menjadi sekor yang memiliki keuntungan lokasional di Kabupaten Gresik, Kabupaten Lamongan, Kota Mojokerto. Konstruksi memiliki keuntungan lokasional di Kabupaten Bangkalan, Kabupaten Gresik, Kabupaten Sidoarjo, Kabupaten Lamongan memiliki keuntungan lokasional di sektor ini. Pengadaan besar dan eceran Sektor ini memiliki keuntungan lokasional di Kabupaten Bangkalan, Kabupaten Gresik, Kabupaten Lamongan. Transportasi dan Pergudangan menjadi sektor yang memiliki keuntungan lokasional di Kabupaten Bangkalan, Kabupaten Gresik, Kabupaten Lamongan, Kabupaten Mojokerto, Kota Mojokerto. Penyediaan akomodasi makanan dan minuman menjadi sektor yang memilki keuntungan lokasional di Kabupaten Bangkalan, Kabupaten Gresik, Kabupaten Sidoarjo, Kabupaten Lamongan. Informasi dan Komunikasi Sektor ini memiliki keuntungan lokasional di Kabupaten bangkalan, Kabuapaten Lamongan, Kabupaten Sidoarjo. Jasa keuangan dan asuransi menjadi sektor yang memiliki keuntungan lokasional di Kabupaten bangkalan, Lamongan, Gresik, Sidoarjo dan Kabupaten Mojokerto. Real estate Sektor ini memiliki keuntungan lokasional di empat daerah yakni Kabupaten Bangkalan, Kabupaten Gresik, Kabupaten Lamongan, Kabupaten Sidoarjo. Jasa Perusahaan Jasa perusahaan memiliki keuntungan lokasional di Kabupaten Gresik dan Lamongan. Administrasi pemerintahan, pertanahan, dan jaminan sosial Sektor ini memiliki keuntungan lokasional di Kabupaten Bangkalan, kabupaten Gresik dan Kabupaten Lamongan dan Kota Mojokerto. Jasa Pendidikan Sektor ini memiliki keuntungan lokasional di Kaupaten Gresik dan Kabupaten Lamongan.Jasa Kesehatan dan kegiatan sosial Kabupaten Lamongan dan Kabupaten Gresik memiliki sektor yang mempunyai keuntungan lokasional. Jasa lainnya Sektor ini mempunyai keuntungan lokasional di kabupaten Gresik dan Kota Mojokerto.

\section{Tipologi Klassen}

Tabel 8.

Hasil Klasifikasi Tipologi Klassen

Daerah Penyangga Surabaya

\begin{tabular}{|c|c|}
\hline KUADRAN I & KUADRAN II \\
\hline Kabupaten Gresik & - \\
\hline Kabupaten Sidoarjo & - \\
\hline Kabupaten Mojokerto & - \\
\hline KUADRAN III & KUADRAN IV \\
\hline Kota Mojokerto & Kabupaten Bangkalan \\
\hline Kota Lamongan & \\
\hline
\end{tabular}

Sumber: BPS, data diolah (2021) 
Melihat dari tabel diatas terlihat bahwa dari keseluruhan Kota/kabupaten di daerah Penyangga Surabaya yang masuk kedalam daerah relatif tertinggal atau Kuadran IV adalah Kabupaten Bangkalan. Kabupaten Lamongan dan Kota Mojokerto masuk kedalam kuadran III yakni wilayah berkembang cepat sedangkan untuk tiga Kabupaten lainnya yakni Kabupaten Sidoarjo, Kabupaten Gresik, Kabupaten Mojokerto masuk kedalam Kuadran I yaitu Daerag maju dan cepat berkembang. Untuk kuadran II tidak ada Kabupaten/Kota yang masuk kedalam kalsifikasi.

\section{Indeks Williamson}

Tabel 9

Indeks Williamson Daerah Penyangga Surabaya

2015-2019

\begin{tabular}{|r|r|}
\hline \multicolumn{1}{|l|}{ Tahun } & $\begin{array}{l}\text { Indeks } \\
\text { Williamson }\end{array}$ \\
\hline 2015 & \\
\hline 2016 & 0.90 \\
\hline 2017 & 0.87 \\
\hline 2018 & 0.91 \\
\hline 2019 & 0.91 \\
\hline Rata-Rata & 0.92 \\
\hline
\end{tabular}

Sumber: BPS data diolah penulis (2021)

Tabel diatas menunjukkan bahwa angka ketimpangan pendapatan di wilayah Penyangga Surabaya tinggi dimana dari tahun 2015 sampai dengan 2019 selalu berada di angka lebih dari 0,35 dengan rata-rata nilai 0,90 hal ini menunjukkan bahwa di wilayah penyangga Surabaya pendapatan daerah relatif tidak merata. Pada tahun 2016 tingkat ketimpangan sempat menurun mnejadi 0,87 dimana tahun sebelumnya 2015 memiliki nilai sebesar 0,90 untuk untuk tahun selanjutnya selalu meningkat hingga tahun 2019 mencapai puncak yakni dengan nilai 0,92 .

\section{E. Pembuktian Teori Kuznets}

Gambar 3 Kurva Kuznets

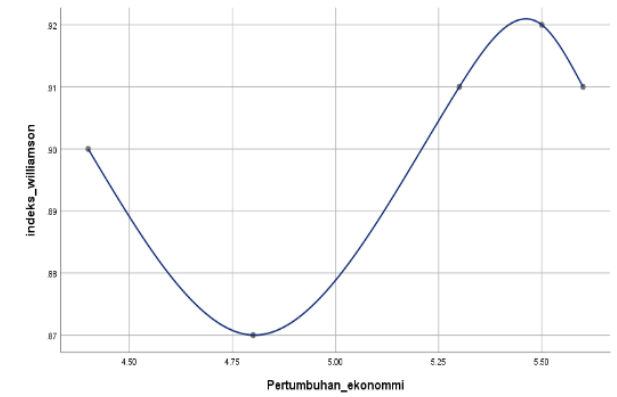

Sumber : BPS data diolah (2021) 
Gambar diatas menunjukkan bahwa hukum hipotesis "U" terbaik kuznets tidak berlaku di daerah penyangga Surabaya, hal ini berarti meskipun terdapat pembangunan yang terus terjadi tidak mengurangi tingkat ketimpangan yang ada di daerah penyangga Surabaya. Faktor-faktornya dari sumber daya yang dimiliki setiap daerah berebeda, jumlah penduduk, kepadatan penduduk, serta tingkat kemiskinan di setiap daerah, pendapatan masyarakat yang berbeda, atau kebijakan pemerintah yang tidak berfokus pada pembangunan.

Nilai ketimpangan pendapatan antar daerah yang dimiliki daerah penyangga Surabaya masih tergolong tinggi, hal ini menunjukkan bahwa belum meratanya pembangunan dan pendapatan daerah. oleh karena itu perlu dilakukan evaluasi dan meningkatkan pembangunan ekonomi di setiap daerah, dimulai dari melihat dan memilah sektor ekonomi yang menjadi basis dan non basis dari setiap daerah, serta melihat bagaimana pengaruh setiap sektor terhadap pertumbuhan ekonomi di setiap daerah yang nantinya dapat dikembangkan dalam pembangunannya sehingga akan berdampak pada pendapatan yang diterima daerah dan dapat mengurangi tingkat disparitas antar daerah.

\section{KESIMPULAN}

\section{KESIMPULAN DAN SARAN}

Berdasarkan analisis yang telah dilakukan penulis di bab IV sebelumnya, maka dapat diambil kesimpulan sebagai berikut:wa

1. Basis ekonomi di Daerah Penyangga Surabaya masih didominasi oleh sektor Pertanian, kehutanan, perikanan, Konstruksi, serta sektor jasa-jasa menjadi sektor basis di hampir tiap Kabupaten/Kota yang ada. Sektor ekonomi yang menjadi potensial dan memiliki kenuntungan lokasional dimana sumber daya yang ada melimpah dapat dikembangkan agar dapat menambah pendapatan daerah.

2. Daerah Penyangga Surabaya memiliki klasifikasi daerah dari 6 Kabupaten/Kota 1 diantara nya masuk kedalam kategori daerah tertinggal yakni Kabupaten Bangkalan, 2 daerah masuk kedalam kategori berkembang cepat merupakan Kabupaten Lamongan dan Kota Mojokerto, dan 3 daerah lainnya masuk kedalam kategori cepat maju dan cepat berkembang adalah Kabupaten Gresik, Kabupaten Sidoarjo, Kabupaten Mojokerto.

3. Ketimpangan pendapatan antar daerah di daerah penyangga Surabaya tergolong Tinggi dimana dengan rata-rata 0,90. Hipotesis Kuznets tidak berlaku di daerah penyangga Surabaya karena seiring bertambahnya waktu pertumbuhan ekonomi meningkat yang juga meningkatkan tingkat ketimpangan pendapatan antar daerah 


\section{SARAN}

Sesuai dengan kesimpulan diatas maka dibawah ini merupakan saran yang di berikan penulis yang nantinya dapat menjadi pertimbangan:

1. Mengurangi ketimpangan pendapatan yang tinggi pemerintah daerah I (Provinsi) bersama Pemerintah daerah II (Kota/Kabupaten) dapat memprioritaskan daerah yang termasuk kedalam daerah tertinggal dan tetap terus membangun daerah yang sudah maju atau sedang berkembang.

2. Pemerintah daerah II (Kota/Kabupaten) memprioritaskan pembangunan dan pengembangan sektor ekonomi yang belum menjadi sektor basis daerah tersebut agar meningkatkan pendapatan daerah tanpa mengabaikan sektor lainnya agar tetap berkembang.

3. pemerintah terus membangun sumberdaya yang manusia di wilayah masing-masing, meningkatkan kualitas pendidikan dan kesehatan akan meningkatkan tingkat IPM sehingga nantinya sumber daya manusia yang ada dapat berkontribusi lebih banyak terhadap pendapatan daerah.

\section{DAFTAR PUSTAKA}

Arsyad, Lincolin. 2010. Ekonomi Pembangunan. Yogyakarta: UPP STIM YKPN.

Badan Pusat Statitik. 2020. Kabupaten Bangkalan dalam Angka 2020. BPS Kabupaten Bangkalan .2020. Kabupaten Gresik dalam Angka 2020. BPS Kabupaten Gresik .2020. Kabupaten Lamongan dalam Angka 2020. BPS Kabupaten Lamongan .2020. Kabupaten Mojokerto dalam Angka 2020. BPS Kabupaten Mojokerto 2020. Kabupaten Sidoarjo dalam Angka 2020. BPS Kabupaten Sidoarjo .2020. Kota Mojokerto dalam Angka 2020. BPS Kota Mojokerto

Badan Pusat Statitik. 2020. Produk Domestik Regional Bruto Lapangan Usaha Atas Dasar Harga Konstan Kabupaten Bangkalan. BPS Jawa Timur

.2020. Produk Domestik Regional Bruto Lapangan Usaha Atas Dasar Harga Konstan Kabupaten Gresik. BPS Jawa Timur 2020. Produk Domestik Regional Bruto Lapangan Usaha Atas Dasar Harga Konstan Kabupaten Kabupaten Mojokerto. BPS Jawa Timur 2020. Produk Domestik Regional Bruto Lapangan Usaha Atas Dasar Harga Konstan Kabupaten Kabupaten Lamongan. BPS Jawa Timur 2020Produk Domestik Regional Bruto Lapangan Usaha Atas Dasar Harga Konstan Kabupaten Sidoarjo. BPS Jawa Timur 2020Produk Domestik Regional Bruto Lapangan Usaha Atas Dasar Harga Konstan Kota Mojokerto. BPS Jawa Timur

2020 Produk Domestik Regional Bruto Lapangan Usaha Atas Dasar Harga Konstan Kota Surabaya. BPS Jawa Timur

Badan Pusat Statitik. 2020. Produk Domestik Regional Bruto Lapangan Usaha Atas Dasar Harga Konstan Provinsi. BPS Jawa Timur

Badan Pusat Statitik. 2020. Jumlah Penduduk Provinsi Jawa Timur menurut Kabupaten/Kota. BPS Jawa Timur 
Eka Raswita, Ngakan, and Made Utama. 2013. "Analisis Pertumbuhan Ekonomi Dan Ketimpangan Pendapatan Antar Kecamatan Di Kabupaten Gianyar." E-Jurnal Ekonomi Pembangunan Universitas Udayana 2(3): 119-28.

Fitrah afrizal, Analisis Pengaruh Tingkat Investasi, Belanja Pemerintah dan Tenaga Kerja Terhadap PDRB di Provinsi Sulawesi Selatan Tahun 2001-2011,Makasar,hlm.12

Fitriyah, Lailatul, Fakultas Ekonomi, and Kampus Ketintang Surabaya. 2013. "3646-5990-1-Pb." ANALISIS KETIMPANGAN PEMBANGUNAN DAERAH SERTA HUBUNGANNYA DENGAN KESEJAHTERAAN MASYARAKAT DI KAWASAN GERBANGKERTOSUSILA PROVINSI JAWA TIMUR.

Indonesia, Bank. 2016a. “(Dated: 3 September 2014) 1.” LAPORAN POSISI INVESTASI INTERNASIONAL INDONESIA TRIWULAN IV 2016 08544(September 2014): 1-12.

_. 2016b. “(Dated: 3 September 2014) 1." laporan possisi investasi internasional indonesia truiwulan IV 2019 08544(September 2014): 1-12.

Iswanto, Denny. 2015. "KETIMPANGAN PENDAPATAN ANTAR KABUPATEN/KOTA Dan PERTUMBUHAN EKONOMI Di PROPINSI JAWA TIMUR." Signifikan: Jurnal Ilmu Ekonomi 4(1): 41-66.

Musfidar, Ma'mun.(2012).Faktor-faktor yang Mempengaruhi Ketimpangan Distribusi Pendapatan di Sulawesi Selatan Tahun 2001-2010. Skripsi Sarjana Jurusan Ilmu Ekonomi pada Fakultas Ekonomi dan Bisnis Universitas Hasanudin Makasar.

Rangkuty, Dewi Mahrani, and Maya Macia Sari. 2019. “Analisis Utang Luar Negeri Dan Inflasi Indonesia." Ekonomikawan: Jurnal Ilmu Ekonomi dan Studi Pembangunan 19(1): 57-66.

Rahardjo Adisasmita, Pertumbuhan Wilayah dan Wilayah Pertumbuhan, Graha Ilmu, Yogyakarta, 2014, hlm. 91.

Rendi Kurniawan, Syamsul Huda. 2020. "Jurnal Dinamika Ekonomi Pembangunan ( JDEP )." JDEP (Jurnal Dinamika Ekonomi Pembangunan) 3(2): 368-75. http://jdep.upnjatim.ac.id/index.php/jdep/article/view/121.

Sari, Norma Rita. 2013. "Provinsi Di Indonesia Tahun 2004-2010."

Setiono, Dedi N.S. (2011). Ekonomi Pengembangan Wilayah: Teori dan Analisis. Fakultas Ekonomi Universitas Indonesia, Jakarta.

Statistik, badan pusat. "PDRB Kota Surakarta Atas Dasar Harga Konstan Menurut Lapangan Usaha." https://surakartakota.bps.go.id/statictable/2020/02/28/150/pdrb-kota-surakarta-atas-dasar-hargaberlaku-menurut-lapangan-usaha-juta-rupiah-2010-2019.html.

Statistik, Badan Pusat. 2016. "PDRB Atas Dasar Harga Konstan 2010." : 10-19.

Supartoyo, Yesi Hendriani, Jen Tatuh, and Recky H. E. Sendouw. 2014. "The Economic Growth and the Regional Characteristics : The Case of Indonesia." Buletin Ekonomi Moneter dan Perbankan 16(1): 3-18.

Sugiyono, 2009, Metode Penelitian Kuantitatif, Kualitatif dan R\&D, Bandung : Alfabeta.

Tarigan, Robinson. (2004). Ekonomi Regional Teori dan Aplikasi. Bumi aksara, Jakarta

Todaro, M.P., dan Smith, S.C. 2006. Pembangunan Ekonomi. Jakarta: Erlangga.. 2006. Pembangunan Ekonomi di Dunia Ketiga. Jakarta: Erlangga.

OKTARI, ASTI (2017) PENGARUH TINGKAT INVESTASI DAN BELANJA PEMERINTAH TERHADAP PRODUK DOMESTIK REGIONAL BRUTO DI PROVINSI LAMPUNG DALAM PERSPEKTIF EKONOMI ISLAM. Undergraduate thesis, UIN Raden Intan Lampung

Wicaksono, Cholif Prasetio. 2010. "Analisis Disparitas Pendapatan Antar Kabupaten/Kota Dan Pertumbuhan Ekonomi Di Propinsi Jawa Tengah Tahun 2003-2007.” Universitas Diponegoro: 155.

YULIANI, TUTIK. 2015. "Pertumbuhan Ekonomi Dan Ketimpangan Pendapatan Antar Kabupaten Di Kalimantan Timur." Jejak 8(1). 